\title{
IDENTIFIKASI FAKTOR-FAKTOR PENCIRI TINGKAT KESEJAHTERAAN RUMAH TANGGA MENGGUNAKAN BOOTSTRAP AGREGATING MULTIVARIATE ADAPTIVE REGRESSION SPLINES (BAGGING MARS) (Kasus Rumah Tangga di Padang Pariaman)
}

\author{
ARIE HARIADY ARIFIN, HAZMIRA YOZZA, IZZATI RAHMI H.G. \\ Program Studi Matematika, \\ Fakultas Matematika dan Ilmu Pengetahuan Alam, Universitas Andalas, \\ Kampus UNAND Limau Manis Padang, Indonesia, \\ ariehariady@gmail.com
}

\begin{abstract}
Abstrak. Tingkat kesejahteraan suatu rumah tangga dapat diduga berdasarkan faktorfaktor pencirinya. Pada penelitian ini akan diidentifikasi faktor-faktor tersebut dengan membuat suatu model klasifikasi berdasarkan faktor-faktor yang diduga menggunakan metode Bagging MARS (Bootstrap Agregating Multivariate Adaptive Regression Splines). Tingkat kesejahteraan rumah tangga dikelompokkan menjadi dua kelompok berdasarkan garis kemiskinan, yaitu miskin dan tidak miskin. Kemudian dibuat model tingkat kesejahteraan berdasarkan 15 variabel yang mewakili aspek kependudukan, pendidikan, perumahan, ketenagakerjaan, sosial ekonomi rumah tangga, dan teknologi informasi dan komunikasi. Data yang digunakan adalah data Hasil Survei Sosial Ekonomi Nasional tahun 2011 di Padang Pariaman. Didapatkan 12 variabel yang berkontribusi pada model. Lima diantaranya yang memiliki tingkat kepentingan tertinggi berturutturut adalah jumlah anggota rumah tangga $\left(X_{5}\right)$, adanya anggota rumah tangga yang dapat menggunakan telepon genggam $\left(X_{14}\right)$, umur kepala rumah tangga $\left(X_{2}\right)$, ijazah tertinggi yang dimiliki kepala rumah tangga $\left(X_{4}\right)$, pengalaman rumah tangga membeli beras raskin $\left(X_{13}\right)$. Selanjutnya variabel-variabel yang berkontribusi pada model didefinisikan sebagai faktor penciri tingkat kesejahteraan rumah tangga.
\end{abstract}

Kata Kunci: Penciri Tingkat Kesejahteraan, Kemiskinan, bagging MARS

\section{Pendahuluan}

Kemiskinan sudah lama menjadi problematika di Indonesia. Pada tahun 2011 BPS mencatat 25,4 juta rumah tangga merupakan penduduk yang termasuk miskin maupun sudah keluar dari batas ambang kemiskinan, tapi masih termasuk kelompok yang rentan untuk jatuh kembali ke bawah batas kemiskinan. Banyak program dan strategi yang dilakukan pemerintah untuk mengentaskan masyarakat dari kemiskinan. Agar program-program tersebut tepat sasaran, harus ada suatu cara untuk mengidentifikasi apakah suatu rumah tangga tersebut miskin atau tidak miskin. Selama ini rumah tangga miskin dikelompokkan berdasarkan pendapatan atau pengeluaran. Namun pendapatan atau pengeluaran tersebut kadang belum menggambarkan kondisi sesungguhnya dari suatu rumah tangga. Untuk itu, perlu 
digunakan cara lain untuk mengidentifikasi tingkat kesejahteraan. Salah satunya dengan melihat faktor-faktor yang dapat menjadi penciri tingkat kesejahteraan suatu rumah tangga.

Pada penelitian ini akan diidentifikasi faktor-faktor tersebut. Hasilnya dapat digunakan untuk perencanaan pembangunan, sehingga pembangunan lebih terarah pada peningkatan kesejahteraan rumah tangga. Untuk mendeskripsikan karakteristik kesejahteraan rumah tangga dan melihat faktor yang paling berpengaruh pada suatu kelompok maka perlu dibuat suatu klasifikasi berdasarkan faktor-faktor yang mempengaruhinya.

Metode klasifikasi yang digunakan dalam penelitian ini adalah MARS (Multivariate Adaptive Regression Splines) yang menghasilkan pemodelan regresi yang fleksibel untuk data dengan variabel prediktor $3 \leq k \leq 20$ dan ukuran contoh $50 \leq n \leq 1000$ [5]. Dalam penelitian ini, metode MARS dikombinasikan dengan salah satu pendekatan non parametrik bootstrap aggregating (bagging). Konsep utama dari bagging adalah menggunakan bootstrap resampling untuk membangkitkan prediktor dalam banyak versi, dimana diharapkan ketika dikombinasikan hasilnya akan lebih baik dari pada prediktor tunggal yang dibangun untuk menyelesaikan permasalahan yang sama.

\section{Kesejahteraan}

Berdasarkan Rancangan Undang-undang tentang Sistem Kesejahteraan Sosial Nasional, kesejahteraan sosial adalah kondisi sosial ekonomi yang memungkinkan bagi setiap warga negara untuk dapat memenuhi kebutuhan yang bersifat jasmani, rohani, dan sosial sesuai dengan harkat dan martabat manusia. Kesejahteraan merupakan kondisi seseorang dapat memenuhi kebutuhan dasar baik material maupun non material yang mencakup aspek gizi dan kesehatan, pengetahuan, dan kekayaan materi [3].

Penduduk miskin adalah penduduk yang memiliki rata-rata pengeluaran perkapita perbulan dibawah penjumlahan dari Garis Kemiskinan Makanan (GKM) dan Garis Kemiskinan Non Makanan (GKNM) [1]. Untuk tahun 2012, garis kemiskin-an yang ditentukan oleh BPS adalah Rp 309.113,00. Penduduk yang memiliki rata-rata pengeluaran perkapita per bulan dibawah garis kemiskinan dikategorikan sebagai penduduk miskin.

Faktor-faktor yang diduga menjadi karakteristik kesejahteraan suatu rumah tangga dapat ditinjau dari beberapa aspek, antara lain: aspek kependudukan, pendidikan, perumahan, sosial ekonomi rumah tangga, dan teknologi informasi dan komunikasi [4].

\section{Multivariate Adaptive Regression Spline(MARS)}

Pada tahun 1990, Jerome H. Friedman memperkenalkan metode MARS sebagai suatu metode baru yang mengotomatiskan pembangunan model-model prediktif akurat untuk variabel-variabel respon kontinu dan biner. MARS merupakan pengembangan dari pendekatan Recursive Partitioning yang menghasilkan model yang tidak kontinu pada knot [5]. 
Beberapa hal yang perlu diperhatikan dalam membangun model MARS yaitu:

- Knot, merupakan nilai variabel prediktor ketika slope suatu garis regresi mengalami perubahan yang dapat didefinisikan sebagai akhir dari satu segmen sekaligus merupakan awal dari segmen yang lain. Di setiap titik knot, diharapkan adanya kontinuitas dari fungsi basis antar satu region dengan region lainnya. Minimum observasi antara knot (MO) yang biasa digunakan adalah $0,1,2$, dan 3 observasi.

- fungsi basis (BF) yaitu selang antar knot yang berurutan. Pada umumnya fungsi basis yang dipilih berbentuk polinomial dengan turunan yang kontinu pada setiap titik knot. Maksimum fungsi basis yang diijinkan adalah 2-4 kali jumlah variabel prediktornya.

- Interaction (interaksi) yaitu hasil perkalian silang antar variabel yang saling berkorelasi. Jumlah maksimum interaksi (MI) yang diperbolehkan adalah 1, 2, atau 3. Jika MI > 3 akan dihasilkan model yang semakin kompleks dan model akan sulit untuk diinterpretasi.

Setelah modifikasi Friedman, model MARS menjadi:

$$
\hat{f}(x)=\alpha_{0}+\sum_{m=1}^{m} \alpha_{m} \Pi_{k=1}^{k_{m}}\left(S_{k m}\left(X_{v(k, m)}-t_{k m}\right)\right)
$$

dengan:

$$
\begin{aligned}
\alpha_{0} & =\text { konstanta regresi dari fungsi basis } \\
\alpha_{m} & =\text { koefisien dari fungsi basis ke-m }, m=1, \ldots, M \\
M & =\text { maksimum fungsi basis (nonconstant fungsi basis) } \\
k m & =\text { derajat interaksi } \\
S_{k m} & =\left\{\begin{array}{l}
+1, \text { jika } k n o t \text { terletak dikanan subregion; } \\
-1, \text { jika } k n o t \text { terletak dikiri subregion. }
\end{array}\right. \\
x_{v(k, m)}= & \text { variabel prediktor ke- } v \text {, pilahan ke- } k \text { dan subregion ke- } m \\
t_{k m}= & \text { nilai } k n o t s \text { dari variabel prediktor } x_{v(k, m)} \\
& \text { koefisien }\left\{\alpha_{m}\right\}_{m=1}^{M} \text { ditentukan dengan metode kuadrat terkecil. }
\end{aligned}
$$

Pembentukan model MARS diawali dengan terlebih dahulu menentukan knot dan fungsi basis setiap variabel prediktor dengan cara memplot setiap variabel prediktor dengan variabel respon. Pemilihan knots pada MARS dilakukan dalam dua tahap yaitu tahap forward dan tahap backward. Forward dilakukan untuk mendapatkan fungsi dengan jumlah basis maksimum dan nantinya akan dipilih fungsi basis dengan metode kuadrat terkecil. Pada tahap backward akan dipilih satu fungsi basis dan mengeluarkan basis tersebut jika kontribusi terhadap model kecil. Proses backward akan dilanjutkan hingga tidak ada fungsi basis yang dapat dikeluarkan. Ukuran kontribusi pada tahap backward ditentukan berdasarkan kriteria Generalized Cross Validation (GCV) yang diperkenalkan oleh Wahba pada tahun 1979. Fungsi GCV didefinisikan sebagai berikut:

$$
G C V(M)=\frac{1 / N \sum_{i=1}^{N}\left[y_{i}-\hat{f}_{M}\left(x_{i}\right)\right]^{2}}{[1-(C(M)) / N]^{2}}
$$


dengan:

$$
\begin{aligned}
M & =\text { jumlah fungsi basis } \\
x_{i} & =\text { variabel prediktor } \\
y_{i} & =\text { variabel respon } \\
N & =\text { banyaknya pengamatan } \\
C(M) & =\operatorname{Trace}\left[B\left(B^{T} B\right)^{-1} B^{T}\right]+1 \\
B & =\left[\begin{array}{ccc}
\prod_{k=1}^{k_{1}}\left(S_{1 M}\left(X_{1(1, M)}-t_{1 M}\right)\right) \cdots & \prod_{k=1}^{k_{m}}\left(S_{k_{m} M}\left(X_{1\left(k_{m}, M\right)}-t_{k_{m} M}\right)\right) \\
\vdots & \ddots & \vdots \\
\prod_{k=1}^{k_{1}}\left(S_{1 M}\left(X_{n(1, M)}-t_{1 M}\right)\right) & \cdots & \prod_{k=1}^{k_{m}}\left(S_{k_{m} M}\left(X_{n\left(k_{m}, M\right)}-t_{k_{m} M}\right)\right)
\end{array}\right]
\end{aligned}
$$

Selanjutnya dilakukan uji signifikansi fungsi basis yang meliputi uji secara bersamaan dan uji individu. Uji signifikansi yang dilakukan secara bersamaan terhadap fungsi basis yang terdapat dalam model MARS ini bertujuan untuk mengetahui apakah secara umum model MARS terpilih merupakan model yang sesuai dan menunjukkan hubungan yang tepat antara variabel prediktor dengan variabel respon. Hipotesis yang digunakan adalah :

$H_{0}: \alpha_{1}=\alpha_{2}=\ldots=\alpha_{m}=0$

$H_{1}:$ ada $\alpha_{j} \neq 0, j=1,2, \ldots, m$

Statistik uji yang digunakan pada pengujian ini adalah statistik uji $\mathrm{F}$ yang diperoleh dari

$$
F_{\text {hitung }}=\frac{\sum_{i=1}^{n}\left(\hat{y}_{i}-\bar{y}\right)^{2} / k}{\sum_{i=1}^{n}\left(y_{i}-\hat{y}_{i}\right) /(n-k-1)} .
$$

Nilai $F_{\text {hitung }}$ ini kemudian dibandingkan dengan $F_{\alpha}\left(v_{1}, v_{2}\right)$ yaitu nilai $\mathrm{F}$ dengan tingkat signifikansi $\alpha$ serta $v_{1}=k$ dan $v_{2}=n-k-1$ dengan $n$ adalah banyaknya sampel dan $\mathrm{k}$ adalah banyaknya fungsi basis yang berkontribusi terhadap model. Jika $F_{\text {hitung }}>F_{\alpha}\left(v_{1}, v_{2}\right)$ maka $H_{0}$ ditolak, artinya paling sedikit ada satu $\alpha_{j}$ yang tidak sama dengan nol.

Bila pada pengujian secara bersamaan disimpulkan untuk tolak $H_{0}$, selanjutnya akan dilakukan pengujian untuk masing-masing fungsi basis yang. Hipotesisnya adalah sebagai berikut:

$H_{0}: \alpha_{j}=0$

$H_{1}: \alpha_{j} \neq 0, j=1,2,, m$

Nilai statistik hitung diperoleh dari $t_{\text {hitung }}=\frac{\alpha_{j}}{s_{\alpha_{j}}}$ dengan $s_{\alpha_{j}}$ merupakan standar error $\alpha_{j}$ yang diperoleh dari

$$
s_{\alpha_{j}}=\sqrt{\left(\frac{\sum_{i=1}^{n}\left(y_{i}-\hat{y}_{i}\right)^{2}}{n-k-1}\right) C_{j j}} .
$$

Nilai $t_{\text {hitung }}$ ini dibandingkan dengan nilai tabel distribusi $t$ dengan derajat bebas $v=n-k-1$ dan tingkat signifikansi $\alpha$. Jika daerah kritis $\left|t_{\text {hitung }}\right|>t\left(\frac{\alpha}{2}, v\right)$, maka $H_{0}$ ditolak, artinya ada pengaruh variabel prediktor pada fungsi basis tersebut terhadap variabel respon.

Selanjutnya digunakan APER (Apparent Error Rate) untuk mengukur peluang 
kesalahan klasifikasi yang dihasilkan MARS. Nilai APER ini menunjukkan proporsi observasi yang salah diklasifikasikan oleh fungsi klasifikasi.

Nilai APER dihitung sebagai berikut,

Keterangan :

$$
\operatorname{APER}(\%)=\frac{n_{12}+n_{21}}{n_{11}+n_{12}+n_{21}+n_{22}} \times 100 \% .
$$

$n_{11}$ : Jumlah kelas aktual 1 yang tepat diklasifikasikan sebagai kelompok 1.

$n_{12}$ : Jumlah kelas aktual 1 yang salah diklasifikasikan sebagai kelompok 2 .

$n_{21}$ : Jumlah kelas aktual 2 yang salah diklasifikasikan sebagai kelompok 1.

$n_{22}$ : Jumlah kelas aktual 2 yang tepat diklasifikasikan sebagai kelompok 2.

\section{Bootstrap Agregating (Bagging)}

Metode bagging pertama kali digunakan oleh Breiman (1994) sebagai alat untuk membentuk pengklasifikasi yang lebih stabil. Bagging predictor adalah metode untuk membangkitkan multiple version dari prediktor dan menggunakannya untuk agregate prediktor. Multiple versions dibentuk dengan replikasi bootstrap dari sebuah dataset.

Misalkan sebuah data set $£$ terdiri dari $\left\{\left(y_{i}, x_{i}\right), i=1,2, \ldots, n\right\}$. Dari data set tersebut, dilakukan pengambilan sampel berukuran $n$ dengan pengembalian sehingga didapatkan $£_{i}^{*}=\left(y_{i}^{*}, x_{i}^{*}\right), i=1,2, \ldots, n$. Pengembalian sampel semacam ini dilakukan sebanyak $B$ kali, sehingga didapatkan $£^{(B)}=\left\{£_{i}^{*}, i=1,2, . ., B\right\}$. Kemudian membuat model klasifikasi MARS dari masing-masing data set hasil sampel bootstrap $£^{(B)}$ sehingga diperoleh klasifikasi bagging dari rata-rata ketepatan klasifikasi pada setiap pengambilan sampel B.

\section{Metode Penelitian}

Data yang digunakan dalam penelitian ini merupakan data hasil Survei Sosial Ekonomi Nasional tahun 2011 (SUSENAS 2011) Kabupaten Padang Pariaman. Variabel respon dalam penelitian ini adalah tingkat kesejahteraan rumah tangga, dimana rumah tangga dibagi menjadi dua kategori, yaitu:

$$
\begin{aligned}
& 1=\text { rumah tangga miskin }, \\
& 2=\text { rumah tangga tidak miskin. }
\end{aligned}
$$

Sedangkan variabel prediktor pada penelitian ini adalah:

$X_{1}=$ Jenis kelamin kepala rumah tangga

$X_{2}=$ Umur kepala rumah tangga

$X_{3}=$ Status perkawinan kepala rumah tangga

$X_{4}=$ Ijazah tertinggi kepala rumah tangga

$X_{5}=$ Jumlah anggota rumah tangga

$X_{6}=$ Kegiatan utama kepala rumah tangga

$X_{7}=$ Status pekerjaan utama kepala rumah tangga

$X_{8}=$ Status penguasaan tempat tinggal

$X_{9}=$ Cara memperoleh air minum 
$X_{10}=$ Sumber penerangan

$X_{11}=$ Bahan bakar energi utama untuk memasak

$X_{12}=$ Pengalaman mendapatkan pelayanan kesehatan gratis selama enam bulan

$X_{13}=$ Pengalaman membeli beras raskin selama tiga bulan terakhir

$X_{14}=$ Ada anggota keluarga yang dapat menggunakan telepon seluler

$X_{15}=$ Ada anggota keluarga yang menguasai komputer/dekstop.

Langkah awal yang dilakukan dalam penelitian ini adalah melakukan analisis statistik deskriptif terrhadap variabel-variabel prediktor. Selanjutnya baru dilakukan pemodelan bagging MARS dengan langkah-langkah sebagai berikut.

(1) Membentuk model MARS terbaik untuk dataset awal dengan mengkombinasikan banyaknya $B F=30,45,60), M I=1,2,3$, dan $M O=0,1,2,3$.

(2) Mendapatkan model MARS terbaik untuk dataset awal berdasarkan nilai GCV terkecil.

(3) Mendapatkan variabel-variabel yang signifikan berpengaruh terhadap model MARS terbaik untuk dataset awal.

(4) Melakukan bagging dari pasangan variabel respon dan variabel prediktor yang siginifikan dari model MARS terbaik untuk dataset awal dengan 15, 20, 25, 30, dan 35 replikasi bootstrap.

(5) Melakukan pemodelan MARS pada setiap pengambilan sampel $B$ replikasi bootstrap dengan jumlah $B F, M I$, dan $M O$ di antara knot yang sama dengan jumlah $B F, M I$, dan $M O$ diantara knot pada model MARS terbaik untuk dataset awal.

(6) Mendapatkan nilai ketepatan klasifikasi pada setiap pengambilan sampel $B$ replikasi bootstrap.

(7) Mendapatkan nilai ketepatan klasifikasi bagging dari rata-rata ketepatan klasifikasi pada setiap pengambilan sampel sampai $B$.

(8) Model bagging MARS yang didapatkan adalah model MARS terbaik untuk data set awal. Hal ini dikarenakan nilai knot yang berubah-ubah untuk setiap replikasi sehungga estimasi parameternya tidak bisa dirata-rata.

(9) Menginterpretasikan tingkat kontribusi variabel prediktor yang mempunyai kepentingan dalam pengelompokan variabel respon.

\section{Analisis dan Pembahasan}

Pembentukan model MARS dilakukan dengan trial and error, dengan mengombinasikan beberapa kriteria model MARS, yaitu jumlah fungsi basis maksimum (BF), maximum interaction (MI), dan minimum observation (MO), sampai diperoleh model terbaik deng-an GCV minimum. Didapatkan model MARS terbaik dengan kombinasi $\mathrm{BF}=60, \mathrm{MI}=3, \mathrm{MO}=1$ dengan $\mathrm{GCV}$ minimum 0,062, yaitu:

$$
\begin{aligned}
Y= & 1,00014+0,78624 * B F_{5}+0,572332 * B F_{7}-0,276479 * B F_{10} \\
& -0,644501 * B F_{11}-0,611178 * B F_{17}-0,0236544 * B F_{20} \\
& -0,20185 * B F_{21}+0,150439 * B F_{23}+0,650067 * B F_{25} \\
& +1,13016 * B F_{29}-0,0412475 * B F_{35}-0,690529 * B F_{37}
\end{aligned}
$$




$$
\begin{aligned}
& +0,0411356 * B F_{39}+0,11673 * B F_{42}-0,022368 * B F_{43} \\
& -0,0459884 * B F_{45}-0,0330924 * B F_{49}+0,0631606 * B F_{51} \\
& -0,0219992 * B F_{53}-0,0767398 * B F_{57} ;
\end{aligned}
$$

dengan

$$
\begin{array}{ll}
B F_{1}=\max \left(0, X_{5}-6\right) ; & B F_{29}=\max \left(0, X_{5}-6\right) * B F_{27} \\
B F_{3}=\left(X_{14} \text { in }(1)\right) ; & B F_{31}=\max \left(0, X_{2}-61\right) \\
B F_{4}=\left(X_{14} \text { in }(2)\right) & B F_{34}=\left(X_{13} \text { in }(1)\right) * B F_{31} \\
B F_{5}=\max \left(0, X_{5}-5\right) * B F_{4} & B F_{35}=\left(X_{12} \text { in }(2)\right) * B F_{34} \\
B F_{7}=\left(X_{10} \text { in }(1)\right) * B F_{5} & B F_{37}=\max \left(0, X_{5}-4\right) * B F_{27} \\
B F_{10}=\max \left(0,36-X_{2}\right) * B F_{5} & B F_{39}=\left(X_{4} \text { in }(3,2,5)\right) * B F_{34} \\
B F_{11}=\max \left(0, X_{5}-4\right) * B F_{4} & B F_{42}=\max \left(0,47-X_{2}\right) * B F_{37} \\
B F_{15}=\left(X_{11} \text { in }(4,5)\right) * B F_{3} & B F_{43}=\left(X_{14} \text { in }(1)\right) * B F_{34} \\
B F_{17}=\left(X_{4} \text { in }(2)\right) * B F_{1} & B F_{45}=\max \left(0, X_{2}-66\right) * B F_{17} \\
B F_{20}=\max \left(0,55-X_{2}\right) * B F_{17} B F_{47}=\max \left(0, X_{5}-3\right) * B F_{4} \\
B F_{21}=\left(X_{8} \text { in }(3)\right) * B F_{11} & B F_{49}=\max \left(0, X_{2}-51\right) * B F_{47} \\
B F_{23}=\max \left(0, X_{2}-72\right) * B F_{17} B F_{51}=\max \left(0, X_{2}-56\right) * B F_{11} \\
B F_{25}=\left(X_{6} \text { in }(1)\right) * B F_{17} & B F_{53}=\left(X_{3} \text { in }(4)\right) * B F_{34} \\
B F_{27}=\left(X_{4} \text { in }(1)\right) & B F_{57}=\left(X_{1} \text { in }(1)\right) * B F_{15}
\end{array}
$$

Berikut adalah interpretasi dari $B F_{10}$ :

$B F_{10}=\max \left(0,36-X_{2}\right) * B F_{5}$

$B F_{5}=\max \left(0, X_{5}-5\right) * B F_{4}$;

$B F_{4}=\left(X_{14}\right.$ in $\left.(2)\right)$;

dengan koefisien -0,276479, artinya setiap kenaikan $B F_{10}$ sebesar satu satuan, akan mengurangi kecendrungan suatu rumah tangga masuk ke dalam kelompok rumah tangga tidak miskin sebesar 0,276479. Berkurangnya kecendrungan rumah tangga ini terjadi jika kepala dari rumah tangga tersebut berumur kurang dari 36 tahun $\left(0,36-X_{2}\right)$ dan jumlah anggota rumah tangga tersebut lebih dari lima orang $\left(0, X_{5}-5\right)$ dan tidak ada anggota keluarga tersebut yang menggunakan telepon genggam $\left(X_{14}\right.$ in $\left.(2)\right)$. Untuk $B F$ lainnya dapat dilakukan interpretasi yang serupa.

Selanjutnya dilakukan uji signifikansi fungsi basis secara keseluruhan (secara serempak/bersama) dengan hipotesis sebagai berikut:

$H_{0}: \alpha_{j}=0$

$H_{1}:$ ada $\alpha_{j} \neq 0$

dengan $j=5,7,10,11,15,17,20,21,23,25,27,29,31,34,35,37,39,42,43,45$, $49,51,53$, dan 57

Berdasarkan hasil pengolahan MARS diperoleh nilai $F_{\text {hitung }}=24,363$. Dengan $\alpha=0,05$, nilai $v_{1}=20$ dan $v_{2}=560$ diperoleh nilai $F_{0.05(20,560)}=1,589$. Karena $F_{\text {hitung }}>1,589$, maka keputusan yang diambil adalah menolak $H_{0}$ yang berarti terdapat paling tidak satu $\alpha_{j}$ yang tidak sama dengan nol atau dengan kata lain terdapat paling tidak satu fungsi basis yang memuat variabel prediktor yang berpengaruh terhadap variabel respon.

Kemudian dilakukan uji secara individual terhadap setiap fungsi basis menggunakan hipotesis sebagai berikut :

$H_{(0)}: \alpha_{j}=0$ 
$H_{(1)}: \alpha_{j} \neq 0$

dengan $j=5,7,10,11,15,17,20,21,23,25,27,29,31,34,35,37,39,42,43,45$, $49,51,53$, dan 57 .

Dalam pengujian ini digunakan $\alpha=0,05$ sehingga $t_{(0,025 ; 560)}=2,247$. Dari perhitungan MARS diperoleh semua fungsi basis menolak $H_{0}$ yang berarti semua fungsi basis yang terpilih dalam model MARS memiliki pengaruh terhadap variabel respon.

Tingkat kepentingan masing-masing variabel prediktor ditunjukkan pada tabel berikut:

Tabel 1. Tingkat Kepentingan Variabel Prediktor

\begin{tabular}{|c|c|c|c|c|c|}
\hline Variabel & Importance & $-\mathrm{GCV}$ & Variabel & Importance & -GCV \\
\hline$X_{5}$ & 100,00 & 0,09353 & $X_{8}$ & 18,09 & 0,06339 \\
$X_{14}$ & 84,20 & 0,08446 & $X_{1}$ & 16,65 & 0,06323 \\
$X_{2}$ & 68,48 & 0,07698 & $X_{11}$ & 16,65 & 0,06323 \\
$X_{4}$ & 62,94 & 0,07472 & $X_{3}$ & 12,08 & 0,06283 \\
$X_{13}$ & 44,68 & 0,06859 & $X_{7}$ & 0 & 0,06283 \\
$X_{10}$ & 37,94 & 0,06686 & $X_{9}$ & 0 & 0,06283 \\
$X_{12}$ & 36,88 & 0,06661 & $X_{15}$ & 0 & 0,06283 \\
$X_{6}$ & 29,83 & 0,06514 & & & \\
\hline \multicolumn{7}{|l}{} \\
\hline
\end{tabular}

Variabel-variabel yang berkontribusi pada model inilah yang didefinisikan sebagai faktor-faktor penciri tingkat kesejahteraan.

Dari klasifikasi tingkat kesejahteraan menggunakan model MARS diperoleh nilai $\mathrm{APER}=6,2 \%$. Sehingga dapat disimpulkan bahwa ketepatan klasifikasi dari pendekatan MARS adalah sebesar 93,8\% dengan tingkat kesalahan 6,2\%.

Selanjutnya dilakukan pendekatan bagging untuk mengetahui akurasi klasifikasi dari model MARS. Pasangan variabel respon dan variabel prediktor yang memberikan kontribusi pada model MARS terbaik direplikasi sebanyak 15, 20, 25, 30, dan 35 kali dengan metode bootstrap. Pada setiap dataset baru $\left\{£^{(B)}\right\}$ hasil replikasi dilakukan pemodelan MARS dengan kriteria $B F, M I$, dan $M O$ yang sama dengan kriteria pembentuk model terbaik, yaitu $B F=60, M I=3$, dan $M O=20$. Didapatkan nilai tingkat kesalahan klasifikasi sebanyak $B$ yang berasal dari pemodelan MARS untuk $\left\{£^{(B)}\right\}$. Selanjutnya tingkat kesalahan klasifikasi baru tersebut dirata-rata sehingga menghasilkan nilai agregat kesalahan klasifikasi ${ }_{B}$.

Tabel 2. Kesalahan Klasifikasi ${ }_{B}$

\begin{tabular}{|c|l|l|l|}
\hline$\left\{£^{(B)}\right\}$ & $\begin{array}{l}\text { Kesalahan } \\
\text { Klasifikasi }_{B}\end{array}$ & $\begin{array}{l}\text { Kesalahan Klasi- } \\
\text { fikasi model MARS } \\
\text { dataset tunggal }\end{array}$ & $\begin{array}{l}\text { Penurunan } \\
\text { kesalahan } \\
\text { klasifikasi }\end{array}$ \\
\hline 15 & 0,0489 & & 0,0131 \\
20 & 0,0496 & & 0,0124 \\
25 & 0,0505 & 0,062 & 0,0115 \\
30 & 0,0505 & & 0,0115 \\
35 & 0,0513 & & 0,0107 \\
\hline
\end{tabular}


Dapat dilihat pada tabel $\left\{£^{(B)}\right\}$ berhasil memberikan akurasi klasifikasi yang lebih baik daripada klasifikasi model MARS dataset tunggal. Penurunan tingkat klasifikasi terbesar diberikan oleh $\left\{£^{(15)}\right\}$.

\section{Kesimpulan}

Dari 15 variabel yang diteliti dalam penelitian ini didapatkan 12 faktor penciri tingkat kesejahteraan rumah tangga, lima diantaranya adalah jumlah anggota rumah tangga $\left(X_{5}\right)$, adanya anggota rumah tangga yang menggunakan telepon seluler $\left(X_{14}\right)$, umur kepala rumah tangga $\left(X_{2}\right)$, ijazah tertinggi yang dimiliki kepala rumah tangga $\left(X_{4}\right)$, pengalaman membeli beras raskin selama tiga bulan terakhir $\left(X_{13}\right)$, dengan tingkat kepentingan masing-masing yaitu $100 \%, 84,20 \%, 68,48 \%$, $62,94 \%$, dan 44,68\%. Dalam penelitian ini, pendekatan bagging dengan 15, 20, 25, 30 dan 35 replikasi terbukti dapat menunjukkan akurasi klasifikasi dari model MARS. Penurunan tingkat klasifikasi terbesar diberikan oleh model MARS bagging dengan 15 replikasi.

\section{Ucapan Terima kasih}

Penulis mengucapkan terima kasih kepada Ibu Hazmira Yozza, M.Si, Ibu Izzati Rahmi H.G, M.Si, Bapak Dr. Dodi Devianto, Ibu Riri Lestari, M.Si, Ibu Dr. Maiyastri, Bapak Yudiantri Asdi, M.Sc dan Ibu Dr. Lyra Yulianti yang telah memberikan masukan dan saran sehingga paper ini dapat diselesaikan dengan baik.

\section{Daftar Pustaka}

[1] Badan Pusat Statistik. 2012. Berita Resmi Statistik: Profil Kemiskinan di Indonesia Maret 2012. BPS. Jakarta

[2] Buhlman, P., Yu, B. 2002. Analyzing bagging, The Annals of Statistics 30 (4) : 927 - 961

[3] Cahyat, A., Gonner, C., dan Haug, M.. 2007. Mengkaji Kemiskinan dan Kesejahteraan Rumah Tangga : Sebuah Panduan dengan Contoh dari Kutai Barat. Indonesia. CIFOR. Bogor.

[4] Dimas, Arvian P. P. 2011. Klasifikasi Kesejahteraan Rumah Tangga di Jawa Timur dengan Pendekatan Multivariate Adaptive Regression Spline - Bootstrap Aggregating (MARS bagging). Tugas Akhir, tidak dipublikasikan, Jurusan Statistika Institut Teknologi Sepuluh Nopember, Surabaya.

[5] Friedman, J.H. 1991. Multivariate Adaptive Regression Splines. The Annals of Statistics, Vol. 19 No. 1. 